Report file no.

GRøNLANDS GEOLOGISKE UNDERSØGELSE

BulletiN No. 79

\title{
A TETRAGONAL NATROLITE
}

CONTRIBUTION TO

THE MINERALOGY OF ILIMAUSSAQ, No. 13

BY

E. KROGH ANDERSEN, MARIANNE DANØ

AND O. V. PETERSEN

\section{WITH A CHEMICAL ANALYSIS \\ BY}

M. MOURITZEN

WITH 1 FIGURE AND 6 TABLES IN THE TEXT

AND 1 PLATE

Reprinted from

Meddelelser om Gronland, Bd. 181, Nr. 10

KØBENHAVN

BIANCO LUNOS BOGTRYKKERI A/S

1969 
GRØNLANDS GEOLOGISKE UNDERSØGELSE

Bulletin No. 79

\title{
A TETRAGONAL NATROLITE
}

CONTRIBUTION TO

THE MINERALOGY OF ILÍMAUSSAQ, No. 13

BY

E. KROGH ANDERSEN, MARIANNE DANØ AND O. V. PETERSEN

\author{
WITH A CHEMICAL ANALYSIS \\ BY \\ M. MOURITZEN
}

WITH 1 FIGURE AND 6 TABLES IN THE TEXT AND 1 PLATE

Reprinted from

Meddelelser om Grenland, Bd.181, Nr. 10

KØBENHAVN

BIANCO LUNOS BOGTRYKKERI A/S 


\begin{abstract}
Tetragonal natrolite has been found as white or, less frequently as, dull pink micro-crystalline aggregates in hydrothermal veins in naujaite, at two separate Iocalities in Ilímaussaq.

The aggregates are built up of sheaf-like groups of prismatic crystals, the greatest dimension of which is about $0.01 \mathrm{~mm}$. The single crystals are bounded by a single prism and either a basal pinacoid or a bipyramid. The density is $2.210 \pm 0.002$.

The mineral is uniaxial, optically positive.

$\mathrm{n}_{\varepsilon}=1.493 \pm 0.001, \mathrm{n}_{\omega}=1.480 \pm 0.001$.

DTA and TGA curves of both ordinary natrolite and tetragonal natrolite are presented; tetragonal natrolite dehydrates at a slightly lower temperature than ordinary natrolite.

The mineral is tetragonal, space group probably $I_{\overline{4}} 2 \mathrm{~d}$. The unit cell dimencions are: $a_{3}=13.043 \pm 0.001 \AA, c_{0}=6.619 \pm 0.001 \AA$, and Vol. $=2252 \AA^{3}$.

The chemical composition of the mineral falls within the range of composition of natrolites as reported in the literature.
\end{abstract}




\section{CONTENTS}

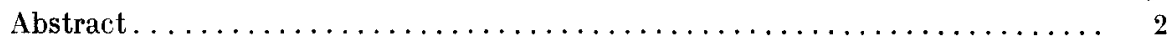

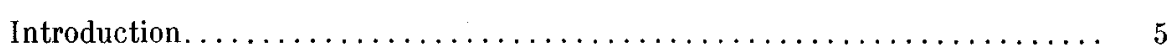

Occurrence. ..................................... 6

Mineralogy . . . . . . . . . . . . . . . .

General description. ............................. 8

Optical properties.............................. 8

Differential thermal analyses and thermogravimetric analyses......... 9

X-ray diffraction.................................. 10

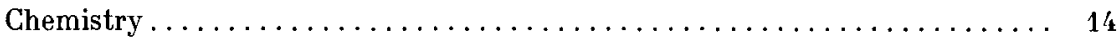

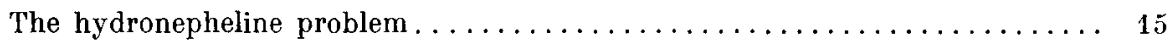

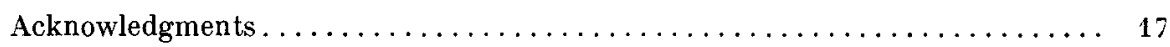

References.................................... 18 


\section{INTRODUCTION}

Tatrolite is orthorhombic but is often described as pseudo-tetragonal. 1 Sørenser (1962), in his detailed petrological description of the steenstrupine-bearing rocks of the Ilimaussaq massif, mentions a white, fibrous, natrolite-like mineral from the border zone of one of the albitites at Tugtup agtakôrfia. The $\mathrm{X}$-ray diagram of this mineral closely resembles that of natrolite. SøRENSEN's preliminary examination suggested that the $\mathrm{X}$-ray diagram of the mineral was identical with that of gonnardite (ranite, see MAson, 1957).

A closer study of Guinier diagrams of both the scanty original material and of several new specimens shows that although it is tetragonal, the mineral is not gonnardite. The diagram is not identical with that of any known mineral and a full description of the mineral is therefore given below. 


\section{OCCURRENCE}

The original material, collected by SøREnSEn, is from a vein of albitite in an inclusion of naujaite in the lujavrite in the westernmost part of Tugtup agtakôrfia. Sørensen's original description of the mineralogy of the vein may be summarized as follows:

Albite is the major component of the greater part of the vein. Scattered through the albite are patches of microcline, crystals of analcite and irregular grains of sodalite. Further components are schizolite, steenstrupine, lepidolite, epistolite, sphalerite, acmite, arfvedsonite and, in the uppermost part of the vein, chkalovite and tugtupite.

Normally the albitite vein has border zones mainly composed of acmite(-aegirine), steenstrupine, analcite, and microcline, with accessory minerals such as sodalite, sphalerite, epistolite, schizolite, lepidolite, and tugtupite (see p. 8).

Sørensen (op. cit. p. 62) describes the occurrence of the natrolitelike mineral as follows: "In some places there is a dense rock rich in a fibrous natrolite-like mineral in the border zone between the vein and naujaite. The fibrous mineral impregnates the naujaite a short distance from the margin of the vein. The white rock has in addition to the accessory minerals mentioned above [sodalite, epistolite, schizolite, lepidolite, and sphalerite] ussingite and small pseudomorphs after eudialyte. A few large prisms of arfvedsonite are almost at right angles to the border. The naujaite adjacent to the vein is often practically unaltered, but locally contains a good deal of the fibrous natrolite-like mineral mentioned above".

The new material, collected during the summer of 1965 by J. HANSEN, originates from veins cutting the naujaite and is mainly composed of aegirine, analcite, natrolite, tetragonal natrolite, chkalovite, beryllite, epistolite, and tugtupite. The following description of the veins is based on the information given by J. HANSEN.

The mineral was found at two localities on the Taseq slope, both at an altitude of $500-550 \mathrm{~m}$ and about $4.8 \mathrm{~km} \mathrm{NW}$ of the original locality. It occurs in late hydrothermal veins which cut the naujaite. The veins, which are up to $1 \mathrm{~m}$ thick, are bordered by zones of felted aegirine. The border zone is followed inwards by zones mainly composed 
of analcite and natrolite. Further constituents of these zones are crystals of chkalovite up to $5 \mathrm{~cm}$ across and microcrystalline aggregates of beryllite. The central part of the veins consists dominantly of the tetragonal mineral; the thickness of the centres varies from a few $\mathrm{cm}$ to $50 \mathrm{~cm}$. Additional constituents of this zone are plates of epistolite up to $10 \mathrm{~cm}$ across and plates of gerassimovskite a few $\mathrm{mm}$ in width. Besides forming a border zone, felted aegirine is found as inclusions in the other zones. J. HANsen, on the basis of field evidence, has suggested that the tetragonal natrolite is formed by alteration of sodalite. 


\section{MINERALOGY}

\section{General description}

The hand specimens examined by the authors from the original locality are of two slightly different kinds.

In most of the specimens the mineral is found as white or, less frequently, as dull pink microcrystalline aggregates consisting of sheaflike groups of small prismatic crystals, together with microcrystalline white tugtupite. The two minerals fill out cavities between well-developed crystals of analcite or less frequently fractures in albite and microcline.

In rare cases the mineral is found as microcrystalline aggregates consisting of radiating groups of needles. These aggregates fill out cavities in a rock almost exclusively composed of felted aegirine. Minor amounts of microcline are often present, minor amounts of analcite only in some cases. Important accessories are small subhedral crystals of steenstrupine and larger plates of epistolite.

The specimens from the new locality are all of the same type. Most specimens consist mainly of white microcrystalline aggregates of the tetragonal natrolite and anhedral colourless grains of analcite. Coarsegrained patches of analcite, grains of sodalite, irregular lumps of felted aegirine and large plates of epistolite are other prominent constituents of the specimens. Microcline and albite are present only in subordinate amounts.

The aggregates of the tetragonal natrolite are built up of sheaf-like groups of prismatic crystals, about $0.01 \times 0.0002 \times 0.0002 \mathrm{~mm}$. The semitransparent, prismatic crystals are bounded by a single prism and either a basal pinacoid or a bipyramid.

No cleavages could be observed, no hardness could be measured, and no crystals large enough for goniometrical measurements have been found. The density, as determined by suspension in heavy liquids, is $\left.2.210 \pm 0.002^{1}\right)$.

\section{Optical properties}

The optical examination was carried out on a powder preparation. Due to the small size of the single crystals which build up the sheaf-like groups, the powder preparation consists of single crystals and not of

1) All the errors indicated refer to standard deviations. 
crystal fragments. The small prismatic crystals are colourless and transparent.

The parallel extinction, the invariable axial figure obtained from all the crystals examined, and the constant values for $n_{\alpha^{\prime}}$ and $n_{\gamma^{\prime}}$ are all consistent with a uniaxial mineral. The mineral is optically positive.

The refractive indices have been determined by means of the $\lambda-\mathrm{T}$ variation method with optical glass as internal standard (MrcheELSEN, 1957) and are:

$$
\begin{aligned}
& \mathrm{n}_{\varepsilon}=1.493 \pm 0.001 . \\
& \mathrm{n}_{\omega}=1.480 \pm 0.001
\end{aligned}
$$

\section{Differential thermal analyses and thermogravimetric analyses}

The DTA curve of natrolite displays an endothermal reaction at about $304^{\circ} \mathrm{C}$ (peak temperature about $328^{\circ} \mathrm{C}$ ), while a similar reaction in

兽 亮总

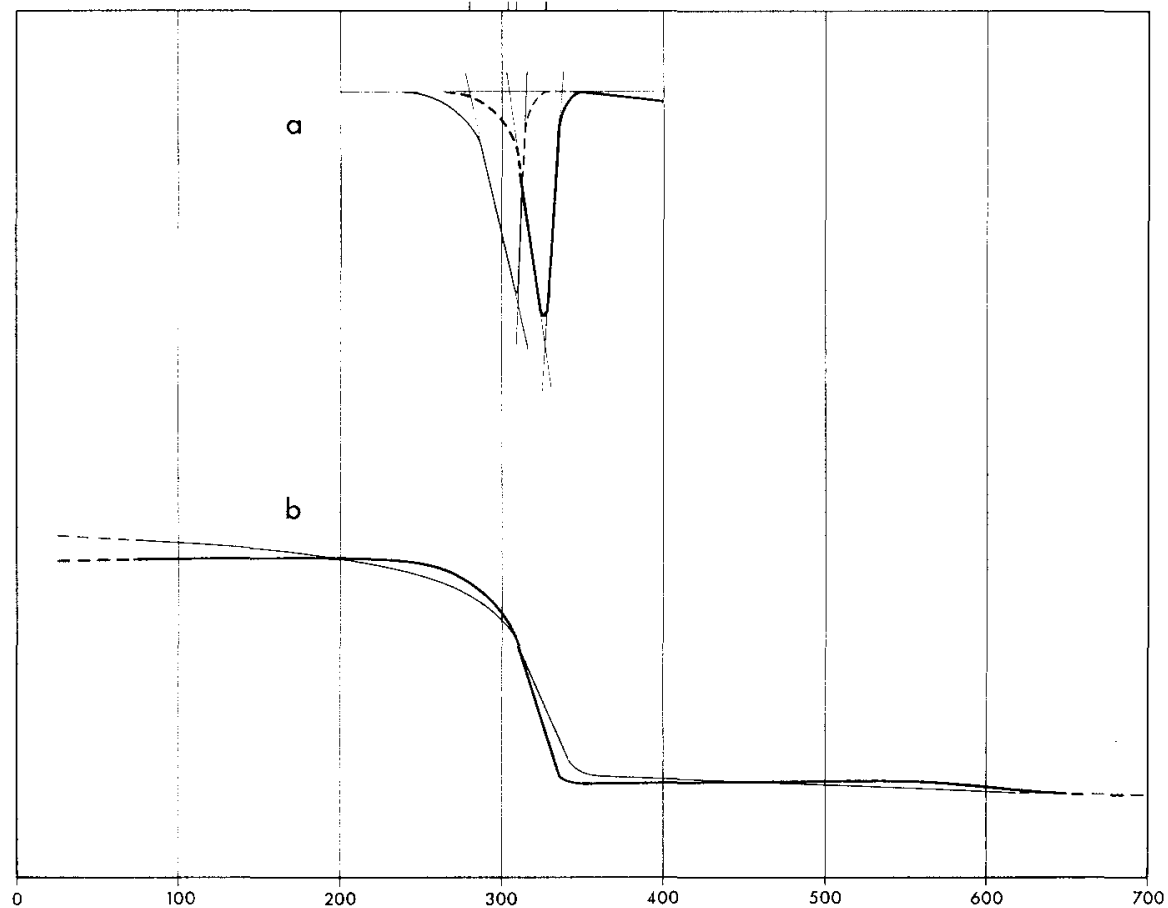

Fig. 1. a: Upper half,

differential thermal analyses of normal natrolite (thick line) and tetragonal natrolite (thin line).

b: Lower half, thermogravimetrical analyses of normal natrolite (thick line) and tetragonal natrolite (thin line).

The curves have been redrawn with an equidistant temperature scale as abscissa. 
the case of tetragonal natrolite takes place at about $280^{\circ} \mathrm{C}$ (peak temperature about $309^{\circ} \mathrm{C}$ ), (see fig. 1 , a).

The TGA curve of natrolite shows a reaction corresponding to a loss of about 9.0 weight per cent of water. The main part of this water is lost in the interval from $275^{\circ} \mathrm{C}$ to $350^{\circ} \mathrm{C}$. The TGA curve of tetragonal natrolite displays a loss of water of about 10.7 weight per cent in the interval from $275^{\circ} \mathrm{C}$ to $350^{\circ} \mathrm{C}$, (see fig. $1, \mathrm{~b}$ ).

The temperature of dehydration of natrolite is seen to be in fair agreement with the data reported in the literature (Sveshnikovr and Kuznetsov, 1946; Peng, 1955; Fang, 1963; and Mayer, Manullova and VARshal, 1964), although perhaps a little low. Tetragonal natrolite dehydrates at a lower temperature than normal natrolite.

\section{X-ray diffraction}

$\mathrm{X}$-ray powder diagrams of normal natrolite and the mineral described here are closely related. Such diagrams are shown in Plate 1. It is seen that several of the lines in normal natrolite are grouped in pairs, and each pair corresponds to only one line in the other diagram. The new mineral appears therefore to be a tetragonal variety of natrolite.

The diagrams shown in Plate 1 have been taken in a Guinier-Hägg camera with quartz as internal standard. The camera was calibrated by means of the observed quartz lines and lattice constants for quartz $\left(a_{0}=4.913, c_{0}=5.405\right)$ as recorded by Swanson \& Fuyat (1953). In this calculation and in the calculation of lattice constants the weighted mean of $\alpha_{1}$ and $\alpha_{2}$ wave-lengths for copper radiation, $1.5418 \AA$, has been used. In the final calculations the reciprocal lattice constants were adapted by the least-squares method to the observed $\sin ^{2} \theta$ values. The resulting calculated $\sin ^{2} \theta$ values are compared with the observed values for both minerals in Table 1 . The lattice constants determined from these sets of $\sin ^{2} \theta$ values are given in Table 2 .

The mean value of $a_{0}$ and $b_{0}$ in normal natrolite (18.457 $\AA$ ) is seen to be almost identical with the a-value in the tetragonal natrolite $(18.446 \AA)$.

In the normal natrolite diagram the following conditions limit the reflections :

$\mathrm{hkl}: \mathrm{h}+\mathrm{k}, \mathrm{k}+\mathrm{l},(\mathrm{l}+\mathrm{h})=2 \mathrm{n}$

$0 \mathrm{kl}: \mathrm{k}+\mathrm{l}=4 \mathrm{n}$

h0l: $\mathrm{h}+\mathrm{l}=4 \mathrm{n}$.

These are the same conditions as found by Meier (1960) and lead to the space group Fdd2 (space group No. 43, International Tables for X-Ray Crystallography. Volume I, 1952). The powder diagram of the 
Table 1. X-ray data of natrolite and tetragonal natrolite.

\begin{tabular}{|c|c|c|c|c|c|c|c|c|c|c|c|c|}
\hline \multicolumn{6}{|c|}{ Natrolite, Glen Farg } & \multicolumn{7}{|c|}{ Tetragonal natrolite } \\
\hline No. & $\begin{array}{l}\text { Int. } \\
\text { (est) }\end{array}$ & $\sin ^{2} \theta_{o b s}$ & $\sin ^{2} \theta_{\text {calc }}$ & $\mathrm{d}_{\mathrm{hkl}} \mathrm{obs}$ & hkl & No. & $\begin{array}{l}\text { Int. } \\
\text { (est) }\end{array}$ & $\sin ^{2} \theta_{o b s}$ & $\sin ^{2} \theta_{\text {ca Ic }}$ & $\mathrm{d}_{\mathrm{hk}} \mathrm{l}_{\mathrm{obs}}$ & hklt) & hkltt) \\
\hline 1 & 4 & .01393 & .01396 & 6.525 & 220 & 1 & 10 & .01392 & .01397 & 6.530 & 220 & 200 \\
\hline 2 & 10 & .01717 & .01720 & 5.879 & 111 & 2 & 20 & .01703 & .01706 & 5.902 & 111 & 101 \\
\hline 3 & 2 & .02742 & .02738 & 4.652 & 040 & & & & & & & \\
\hline 4 & 1 & .02847 & .02847 & 4.565 & 400 & 3 & 5 & .02789 & .02794 & 4.612 & 400 & 220 \\
\hline 5 & 5 & .03086 & .03089 & 4.385 & 131 & & & & & & & \\
\hline 6 & 6 & .03145 & .03144 & 4.344 & 311 & 4 & 10 & .03097 & .03103 & 4.377 & 311 & 211 \\
\hline 7 & 2 & $.03279 *)$ & & 4.254 & & 5 & 5 & $\left..03284^{*}\right)$ & & 4.251 & & \\
\hline 8 & 3 & .03449 & .03449 & $4: 148$ & 240 & & 5 & 02480 & & 4701 & & \\
\hline 9 & 2 & .03530 & .03531 & 4.100 & 420 & b & $b$ & .034 & .03493 & 4.124 & 420 & 310 \\
\hline 10 & 15 & $\left..05323^{*}\right)$ & & 3.339 & & 7 & 20 & $\left..05308^{*}\right)$ & & 3.343 & & \\
\hline 11 & 1 & .05577 & .05584 & 3.262 & 440 & & & & & & & \\
\hline 12 & 5 & .05827 & .05827 & 3.191 & 151 & & & & & & & \\
\hline 13 & 6 & .05988 & .05991 & 3.148 & 511 & 8 & 10 & .05899 & .05897 & 3.171 & 511 & 321 \\
\hline 14 & 5 & .06187 & $\left\{\begin{array}{l}.06170 \\
.06197\end{array}\right.$ & 3.097 & $\left\{\begin{array}{l}022 \\
202\end{array}\right.$ & 9 & 5 & .06120 & .06124 & 3.114 & 202 & 112 \\
\hline 15 & 1 & .06471 & Imp. & 3.028 & & & & & & & & \\
\hline 16 & 6 & .06880 & .06882 & 2.937 & 222 & 10 & 5 & .06820 & .06823 & 2.949 & 222 & 202 \\
\hline & & & & & & 11 & 1 & .06986 & .06986 & 2.914 & 620 & 420 \\
\hline 17 & 7 & .07249 & .07250 & 2.861 & 351 & & & & & & & \\
\hline 18 & 6 & .07358 & .07359 & 2.840 & 531 & 12 & 20 & .07297 & .07295 & 2.851 & 531 & 411 \\
\hline 19 & 2 & .08936 & .08935 & 2.577 & 242 & & & & & & & \\
\hline 20 & 2 & .09011 & .09017 & 2.566 & 422 & 13 & 5 & .08915 & .08919 & 2.580 & 422 & 312 \\
\hline 21 & 1 & $\left..09847^{*}\right)$ & & 2.455 & & 14 & 3 & $\left..09849^{*}\right)$ & & 2.454 & & \\
\hline 22 & 2 & .09935 & .09933 & 2.444 & 171 & & & & & & & \\
\hline 23 & 2 & .10261 & .10261 & 2.405 & 711 & 15 & 5 & . 10085 & .10089 & 2.425 & 711 & 501 \\
\hline 24 & 1 & .10957 & .10950 & 2.327 & 080 & & & & & & & \\
\hline 25 & 1 & .11071 & .11070 & 2.315 & 442 & 16 & 1 & .11007 & .11015 & 2.322 & 442 & 402 \\
\hline 26 & 1 & $\left..11425^{*}\right)$ & & 2.279 & & 17 & 3 & $\left..11429^{*}\right)$ & & 2.278 & & \\
\hline 27 & 1 & .11641 & .11645 & 2.258 & 062 & 18 & 1 & .11 & .11713 & 2.250 & 602 & 332 \\
\hline 28 & 1 & .11881 & .11891 & 2.235 & 602 & 18 & 1 & & .11013 & 2.200 & buz & 552 \\
\hline & 1 & $\left..11881^{*}\right)$ & .1189 .1 & 2.235 & & 19 & 2 & $\left..11878^{*}\right)$ & & 2.235 & & \\
\hline 29 & 2 & .12359 & .12357 & 2.191 & 262 & 20 & 3 & 12407 & 12412 & 2.187 & 622 & 422 \\
\hline 30 & 2 & .12570 & .12575 & 2.173 & 622 & 20 & 3 & .12407 & .12412 & 2.187 & 622 & \\
\hline 31 & 1 & $\left..13134^{*}\right)$ & & 2.125 & & 21 & 3 & $\left..13136^{*}\right)$ & & 2.125 & & \\
\hline 32 & 1 & .14098 & .14125 & 2.051 & 840 ? & 22 & 2 & .13966 & .13972 & 2.061 & 840 & 620 \\
\hline 33 & 1 & $\left..15162^{*}\right)$ & & 1.978 & & 23 & 2 & $\left..15162^{*}\right)$ & & 1.978 & & \\
\hline 34 & 1 & .15476 & .15484 & 1.958 & 333 & & & & & & & \\
\hline 35 & 1 & .16809 & .16798 & 1.879 & 153 & & & & & 1881 & 513 & 393 \\
\hline 36 & 1 & .16957 & .16962 & 1.870 & 513 & 24 & 3 & & & 81 & b13 & \\
\hline 37 & 1 & .17811 & .17821 & 1.825 & 2100 & & & & & & & \\
\hline 38 & 1 & $\left..17999^{*}\right)$ & & 1.816 & & 25 & 5 & $\left..17988^{*}\right)$ & & 1.816 & & \\
\hline & & & & & & 26 & 5 & .18166 & .18164 & $1.807=$ & 020 & 640 \\
\hline 39 & 1 & .18201 & .18221 & 1.805 & 353 & & & & & & & \\
\hline 40 & 1 & $\left..18337^{*}\right)$ & .18331 & 1.799 & $533 ?$ & & & & & & & \\
\hline 41 & 1 & .18475 & $\int .18473$ & 1.792 & 771 & & & & .18472 & 1.792 & 771 & 701 \\
\hline 42 & 1 & 19279 & $\begin{array}{r}.18477 \\
19283\end{array}$ & 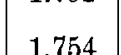 & 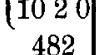 & & & & & & & \\
\hline 43 & $\begin{array}{l}1 \\
1\end{array}$ & $\begin{array}{l}.10210 \\
.19616\end{array}$ & .19610 & $\begin{array}{l}1.164 \\
1.739\end{array}$ & $\begin{array}{l}404 \\
842\end{array}$ & 28 & 2 & .19389 & 19398 & 1.749 & 842 & 622 \\
\hline 44 & 1 & .19965 & .19956 & 1.724 & 4100 & & & & & & & \\
\hline
\end{tabular}

*) Quartz. f) F-centered lattice.

tt) I-centered lattice. 
Table 2. Unit-cell parameters of natrolite, Glen Farg, and tetragonal natrolite.

\begin{tabular}{c|c}
\hline $\begin{array}{l}\text { Natrolite } \\
\text { Glen Farg }\end{array}$ & $\begin{array}{c}\text { Tetragonal } \\
\text { natrolite }\end{array}$ \\
\hline $\begin{array}{l}\mathrm{a}_{0}=18.276 \pm 0.003 \AA \\
\mathrm{c}_{0}=18.637 \pm 0.002 \AA \\
\mathrm{b}_{0}=6.583 \pm 0.001 \AA\end{array}$ & $\mathrm{a}_{0}=18.446 \pm 0.002 \AA$ \\
\hline
\end{tabular}

new mineral has the same conditions to limit the reflections and must hence belong to one of the tetragonal space groups $F 4_{1} \mathrm{dm}$ or $F \overline{4} \mathrm{~d} 2$. In the standard setting these groups are identical with $I 4_{1}$ md and $I \overline{4} 2 \mathrm{~d}$ which are indistinguishable from systematic extinction of $\mathrm{X}$-ray reflections alone. Since natrolite has an arrangement of the atoms with almost $\overline{4}$ symmetry, the space group I $\overline{4} 2 \mathrm{~d}$ seems to be the most probable for the new mineral. In the I-setting the axes are

$$
\mathrm{a}_{0}=13.043 \pm 0.001 \AA \text { and } \mathrm{c}_{0}=6.619 \pm 0.001 \AA .
$$

In Table 1 are given hkl for both settings of tetragonal natrolite.

Neither the ASTM Powder Diffraction File 1963 nor Donnay et al. (1963) report any crystalline material with X-ray properties similar to those of the tetragonal natrolite.

Peng (1955) has published X-ray data for a mineral which he considered to be anhydrous natrolite. The d-values reported by PENG indicate that the unit cell of this phase is larger than that of normal natrolite. As pointed out by EDGAR (1965) this is inconsistent with the data reported by FANG (1963), who found that the "anhydrous" form of natrolite has a smaller cell size than the "hydrous" natrolite. EDGAR (1965, p. 988) concluded that the phase examined by PENG cannot be an anhydrous form of natrolite.

In Table $3 \mathrm{~d}$-values of the natrolite (Glen Farg) and the tetragonal natrolite (Ilímaussaq) presented in Table 1 of the present paper are listed together with those published by PENG (1955) for natrolite and "anhydrous" natrolite. It appears from Table 3 that the d-values published by PENG for natrolite and "anhydrous" natrolite and those published by the authors for tetragonal natrolite are practically identical. However, the X-ray technique used by PENG does not permit observation of the orthorhombic splitting up of reflections $\mathrm{hkl}$ and $\mathrm{khl}$; hence there is no reason to believe that the anhydrous natrolite is tetragonal any more than the natrolite used for comparison.

According to SAHA (1961) some of the natural alteration products og nepheline might be identical with the synthetic compound nepheline hydrate I. However, as discussed by EDGAR (1964 and 1965) and SAHA 
Table 3. Comparison of d-values of natrolite, Glen Farg, the natrolite and anhydrous natrolite of PeNG (1955), and tetragonal natrolite.

\begin{tabular}{|c|c|c|c|c|c|}
\hline \multicolumn{2}{|c|}{$\begin{array}{l}\text { Natrolite, Glen Farg } \\
\text { (transferred from Table 1) }\end{array}$} & \multicolumn{2}{|c|}{\begin{tabular}{c|c} 
Natrolite & $\begin{array}{c}\text { Anhydrous } \\
\text { natrolite }\end{array}$ \\
(PENG 1955)
\end{tabular}} & \multicolumn{2}{|c|}{$\begin{array}{c}\text { Tetragonal natrolite } \\
\text { (transferred from Table 1) }\end{array}$} \\
\hline $\mathrm{hkl}$ & $d_{o b s}$ & $\mathrm{~d}_{\text {obs }}$ & $d_{o b s}$ & $d_{o b s}$ & $\mathrm{hkl}$ \\
\hline 220 & 6.525 & 6.44 & 6.46 & 6.530 & 220 \\
\hline 111 & 5.879 & 5.81 & 5.85 & 5.902 & 111 \\
\hline 040 & $4.652\}$ & 4.57 & 4.62 & 4.612 & 400 \\
\hline 400 & $4.565\}$ & 4.08 & 4.02 & 4.012 & \\
\hline 131 & 4.385 ) & 4.32 & 4.35 & 4.377 & 311 \\
\hline 311 & $4.344\}$ & 4.32 & 4.30 & 4.568 & 311 \\
\hline 240 & $4.148\}$ & 4.10 & 4.14 & 4.124 & 420 \\
\hline $\begin{array}{c}420 \\
\ldots\end{array}$ & $\begin{array}{c}4.100 J \\
\ldots\end{array}$ & 3.48 & 3.48 & $\ldots$ & .. \\
\hline 440 & 3.262 & .. & .. & .. & .. \\
\hline 151 & $3.191\}$ & & $3.18)$ & & \\
\hline 511 & $3.148\}$ & 3.18 & $3.14\}$ & 3.171 & 511 \\
\hline $\left.\begin{array}{l}022 \\
202\end{array}\right\}$ & 3.097 & .. & 3.09 & 3.114 & 202 \\
\hline 222 & 2.937 & 2.93 & 2.94 & 2.949 & 222 \\
\hline$\ldots$ & .. & .. & .. & 2.914 & 620 \\
\hline 351 & $2.861\}$ & 2.83 & 2.85 & 2.851 & 531 \\
\hline 531 & $2.840\}$ & 6.00 & 2.00 & & \\
\hline . & . & 2.66 & .. & . & .. \\
\hline 242 & $2.577\}$ & 2.57 & 2.57 & 2.580 & 422 \\
\hline 422 & $\begin{array}{l}2.566 f \\
2.444\end{array}$ & 243 & 2441 & & \\
\hline 171 & $\begin{array}{l}2.444 \\
2.405\end{array}$ & $\begin{array}{l}2.45 \\
2.41\end{array}$ & $\begin{array}{l}2.44 \\
241\end{array}$ & 2.425 & 711 \\
\hline 711 & $\begin{array}{l}2.405 \\
9.397\end{array}$ & $\begin{array}{l}2.41 \\
232\end{array}$ & $\begin{array}{l}2.41 \mathrm{~J} \\
9.39\end{array}$ & & \\
\hline 080 & 2.327 & 2.32 & & .. & .. \\
\hline 442 & 2.315 & .. & .. & 2.322 & 442 \\
\hline 062 & $2.258\}$ & 2.25 & 2.25 & 2.250 & 602 \\
\hline 602 & $2.235\}$ & & & & \\
\hline $\begin{array}{l}262 \\
622\end{array}$ & $\left.\begin{array}{l}2.191 \\
2.173\end{array}\right\}$ & 2.17 & 2.18 & 2.187 & 622 \\
\hline 480 & . & & & & \\
\hline $840 ?$ & $2.051\}$ & 2.06 & 2.06 & 2.061 & 840 \\
\hline 333 & 1.958 & 1.96 & 1.96 & . & .. \\
\hline 153 & $1.879)$ & 187 & 1.93 & 1.881 & 513 \\
\hline 513 & $1.870\}$ & & & & \\
\hline
\end{tabular}

(1959 and 1961) nepheline hydrate I is probably unstable under the physical-chemical conditions of alteration of natural nepheline.

The optical and chemical data published by BARrer and White (1952) for nepheline hydrate I recall those of tetragonal natrolite; but the X-ray data of nepheline hydrate I reported by BARRER and White 
(ap. cit.) and by EDGar (1964) are so different from those of tetragonal natrolite that this possibility is definitely excluded.

The $\mathrm{X}$-ray data of tetragonal natrolite are also inconsistent with those reported by BRECK et al. (1956) and SAHA (1961) for the synthetic compounds "zeolite A" and "zeolite B" which chemically are rather close to tetragonal natrolite and with the paranatrolite reported by MAYES, Manuilova, and Varshal (1964). Senderov and Yuknevich (1961) have rejected the existence of paranatrolite.

\section{Chemistry}

In Table 4 the chemical analysis of tetragonal natrolite is compared with the four chemical analyses of natrolite reported by DEER, Howie and Zussman (1963). It is seen that the chemical composition of the tetragonal natrolite does not differ from that of normal natrolite. As the unit cell volume and the density of the two minerals are almost the same, the cell content in both types of natrolite is 8 units of $\mathrm{Na}_{2} \mathrm{Al}_{2} \mathrm{Si}_{3} \mathrm{O}_{10}$ $\cdot 2 \mathrm{H}_{2} \mathrm{O}$.

Table 4. Chemical analyses, and numbers of atoms corresponding to $A l+S i=40.00$, of the tetragonal natrolite and four natrolites reported in DEER, HowIE and Zussman (1963), and weight $\%$ oxides corresponding to the formula $\mathrm{Na}_{2} \mathrm{Al}_{2} \mathrm{Si}_{3} \mathrm{O}_{10} \cdot 2 \mathrm{H}_{2} \mathrm{O}, \mathrm{Z}=8$.

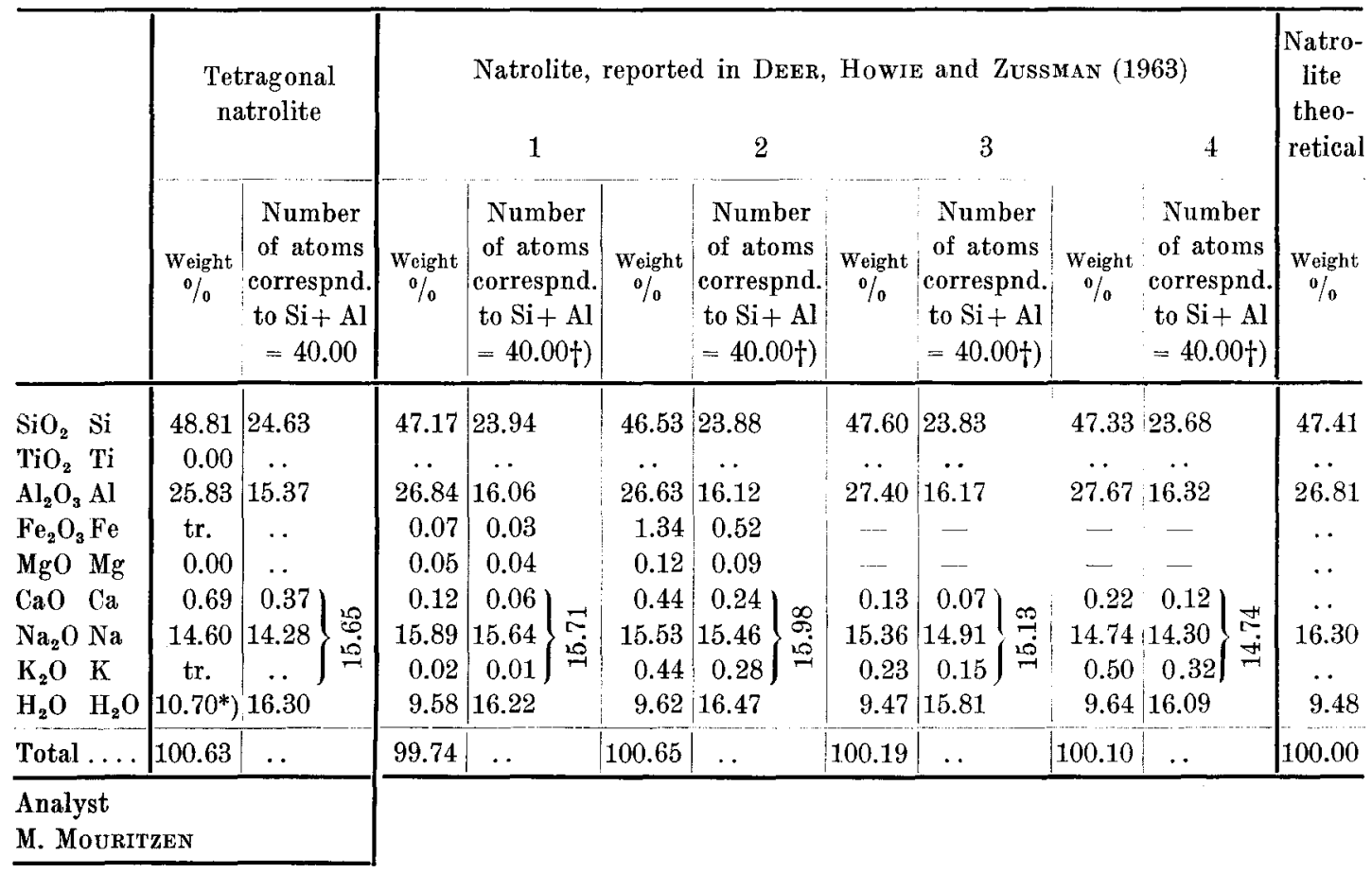

*) From the thermogravimetric analysis.

t) Recalculated from DeER, Howie and Zussman's, numbers of ions on the basis of 80 oxygens. 


\section{THE HYDRONEPHELINE PROBLEM}

It will be seen from the previous sections that the mineral described, as far as the optical properties and the paragenesis are concerned, resembles the doubtful species hydronepheline (Clarke, 1886).

The chemical composition of the tetragonal natrolite, however, is rather different from the chemical composition of the minerals involved in the hydronepheline problem, see Table 5.

Table 5. Chemical analyses of hydronepheline, rauit (-ranite), gonnardite and tetragonal natrolite.

\begin{tabular}{|c|c|c|c|c|}
\hline & $\begin{array}{l}\text { Hydronepheline } \\
\text { (CLARKE, } \\
1886)\end{array}$ & $\begin{array}{c}\text { Rauit } \\
\text { (-ranite) } \\
\text { (PAIJKULL, } \\
1874)\end{array}$ & $\begin{array}{c}=*) \text { Gonnardite } \\
(\text { GonNARD } \\
1871) \dagger)\end{array}$ & $\begin{array}{c}\text { Tetragonal } \\
\text { natrolite }\end{array}$ \\
\hline & $\begin{array}{c}\text { Weight } \\
\%\end{array}$ & $\begin{array}{c}\text { Weight } \\
\%\end{array}$ & $\begin{array}{c}\text { Weight } \\
\%\end{array}$ & $\begin{array}{l}\text { Weight } \\
\%\end{array}$ \\
\hline $\mathrm{SiO}_{2}$. & 38.99 & 39.21 & 42.3 & 48.81 \\
\hline $\mathrm{Al}_{2} \mathrm{O}_{3} \ldots$ & 33.62 & 31.79 & 28.1 & 25.83 \\
\hline $\mathrm{Fe}_{2} \mathrm{O}_{3} \ldots$ & . & 0.57 & .. & tr. \\
\hline MnO.. & .. & .. & .. & .. \\
\hline $\mathrm{MgO} . . .$. & .. & .. & .. & 0.00 \\
\hline $\mathrm{CaO}$. & 0.07 & 5.07 & 10.0 & 0.69 \\
\hline $\mathrm{Na}_{2} \mathrm{O}$. & 13.07 & 11.55 & 6.7 & 14.60 \\
\hline $\mathrm{K}_{2} \mathrm{O}$. & 1.12 & . & n.d. & tr. \\
\hline $\mathrm{H}_{2} \mathrm{O}$. & 12.98 & 11.71 & 14.1 & 10.70 \\
\hline Total. & 99.85 & 99.90 & 101.2 & 100.63 \\
\hline
\end{tabular}

*) See Mason (1957).

†) Identified as mesolite, shown by Lacrorx (1896) to be a new mineral and named gonnardite.

In order to compare the X-ray data the unit-cell parameters are listed in Table 6.

Unfortunately the unit-cell dimensions of the type material of hydronepheline have not been published.

Gonnardite (ranite) has unit-cell constants comparable with those of tetragonal natrolite, but powder diagrams of gonnardite (see MEIXnER, 
Table 6. Unit-cell parameters of tetragonal natrolite and minerals related to the hydronepheline problem.

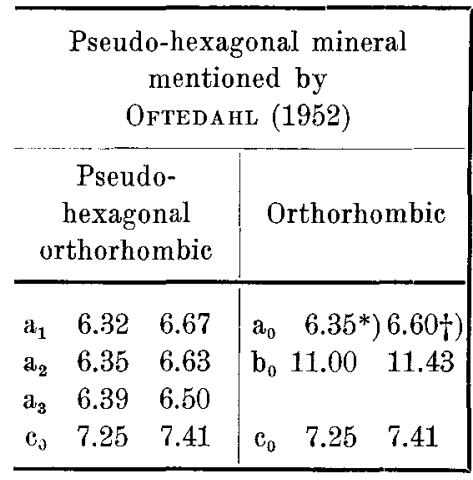

\begin{tabular}{|c|c|c|c|}
\hline $\begin{array}{c}\text { Gonnardite } \\
\text { (-Ranite) } \\
\text { (HEx,1932) }\end{array}$ & $\begin{array}{c}\text { Tetragonal } \\
\text { natrolite }\end{array}$ & $\begin{array}{l}\text { Natrolite } \\
\text { Glen Farg }\end{array}$ & $\begin{array}{c}\text { Tetragonal } \\
\text { natrolite }\end{array}$ \\
\hline $\begin{array}{l}\text { Ortho- } \\
\text { rhombic }\end{array}$ & $\begin{array}{c}\text { Tetragonal } \\
\text { I-centered } \\
\text { lattice }\end{array}$ & $\begin{array}{l}\text { Ortho- } \\
\text { rhombic }\end{array}$ & $\begin{array}{l}\text { Tetragonal } \\
\text { F-centered } \\
\text { latice }\end{array}$ \\
\hline $\begin{array}{ll}\mathrm{a}_{0} & 13.38 \\
\mathrm{~b}_{0} & 13.38\end{array}$ & $a_{0}=b_{0} 13.043$ & $\begin{array}{ll}\mathrm{a}_{0} & 18.276 \\
\mathrm{~b}_{0} & 18.637\end{array}$ & $a_{0}=b_{0} 18.446$ \\
\hline $\begin{array}{cc}c_{0} & 6.66\end{array}$ & 6.619 & $\mathbf{c}_{0} \quad 6.583$ & 6.619 \\
\hline
\end{tabular}

*) Average of first column of $a_{1}, a_{2}, a_{3}$.

$\dagger$ Average of second colnmn of $a_{1}, a_{2}, a_{3}$.

HeY and Moss, 1956) show differences in both position and intensity of the lines. For comparison the pseudo-hexagonal mineral mentioned by OfTEDahl (1952) has been indexed by the authors on orthorhombic axes; however, the parameters are seen to be quite different from those of tetragonal natrolite, and as no powder data are given no other indexing can be tried.

Ussivg (1898) mentions a zeolite occurring as an alteration product of nepheline, which is uniaxial, optically positive, length slow, with refractive indices equal to those of natrolite, and which he considered to be hydronepheline. Unfortunately the material is not available for further investigation. The apparent uniaxial character of this mineral may, as suggested by OFtEDAHL (op. cit., p. 2) be explained as a result of the way in which the individuals are built up; one individual is built up of several fibres. These fibres have parallel c-axes, but have random orientation of their $\mathrm{a}$ and $\mathrm{b}$ axes, thus creating a pseudo-uniaxial symmetry.

It must be concluded that the tetragonal natrolite is not identical with what is called hydronepheline or with minerals described as closely related to hydronepheline; the chemical and $\mathrm{X}$-ray properties are too different. The tetragonal natrolite is, however, closely related to natrolite. 


\section{Acknowledgments}

The authors wish to thank Professor H. Sørensen for providing the material and for invaluable assistance during the work.

The authors also wish to thank Miss M. Mouritzen for making the chemical analysis.

Thanks are also due to Mr. J. Hansen for handing part of the material over to the authors, to Mrs. Ragin Larsen, who drew the figure, to Mrs. Maren Grumløse, who typed the manuscript, and to Mr. G. Henderson, who kindly corrected the English of the manuscript.

The material was collected during the investigations in the Ilimaussaq intrusion being carried out by Grønlands Geologiske Undersøgelse (the Geological Survey of Greenland) under the direction of Professor H. Sørensen. The authors wish to thank the Director of the Geological Survey of Greenland, K. Ellitsgaard-Rasmussen, for permission to publish this report. 


\section{REFERENCES}

Barrer, R. M. and White, E. A., 1952: The hydrothermal chemistry of the silicates. Part II, synthetic crystalline alumosilicates. Journ. Chem. Soc., 286, 1561-1571.

Breck, D. W., Eversole, W. G., Milton, R. M., Reed, T. B., and Thomas, T. L., 1956: Crystalline zeolites. I. The properties of a new synthetic zeolite, type A: Journ. Am. Chem. Soc., 78, 5963-5971.

Cla ke, F. W., 1886: Minerals from Litchfield, Maine. Amer. J. Sci., 31, p. 262.

Deer, W. A., Howie, R. A., and Zussman, J., 1963: Rock-Forming Minerals. Vol. IV., Longmans, London.

Donnay, J. D. H., Donnay, G., Cox, E. G., Kennard, O., and King, M. V., 1963: Crystal data. Determinative tables. Amer. Cryst. Assoc. Monograph No. 5.

EdGar, A. D., 1964: A note on the lattice parameters of nepheline hydrate I. Amer. Miner., 49, 1139-1141.

- 1965: The mineralogical composition of some nepheline alteration products. Amer. Miner., 50, 978-989.

FANG, J. H., 1963: Cell dimensions of dehydrated natrolite. Amer. Miner., 48, 414417.

Gonnard, F., 1871: Sur les dolérites de la Chaux de Bergonne et sur les zeolithes qu'elles contiennent. Compt. Rend. Acad. Sci., Paris, 73, 1447-1449.

HEY, M. H., 1932: Studies on the zeolites. Part II. Thomsonite (including faroelite) and gonnardite. Miner. Mag., Vol. 23, No. 137, p. 51-125.

International Tables for X-Ray Crystallography, 1952: Vol. I. Birmingham, Kynoch Press.

Lacroix, A., 1896: Sur la gonnardite. Bull. Soc. Franc. Min. 19, 426-429.

Mason, B., 1957: Gonnardite (Ranite) from Langesundsfjord. Norsk geol. Tidsskr., 37, p. 435-437.

Mayer, A. A., Manullova, N. S., and Varshall, B. G., 1964: Transformation of natrolite under hydrothermal conditions. Dokl. Acad. Sci. U.S.S.R., Earth Sci. Sect., 154, 89-92. Transl. from Dokl. Akad. Nauk. SSSR, 1964, 154, 363-365.

Meier. W. M., 1960: The crystal structure of natrolite. Zeit. Krist., Bd.113, p. 430-444.

Meixner, H., Hex, M. H., and Moss, A. A., 1956: Some new occurrences of gonnardite. Miner. Mag., 31, p. 265-271.

MICHEELSEN, H., 1957: An immersion method for exact determination of refractive indices. The glass method. Medd. dansk geol. Foren., Bd. 13, p. 177-191.

Oftedahl, C., 1952: On "apoanalcite" and hydronepheline. Norsk geol. Tidsskr., 30, p. $1-4$.

PaIJ Kuxh, S. R., 1874: Rauit, ein neues Mineral von Brewig. Ber. deutsch. Chem. Gesell., 7, p. 1334-1335.

Peng, C. J., 1955: Thermal analysis study of the natrolite group. Amer. Miner., 40, 834-856. 
SAHA, P., 1959: "Subsolidus studies in the system $\mathrm{NaAlSiO}_{4}-\mathrm{NaAlSi}_{3} \mathrm{O}_{8}-\mathrm{H}_{2} \mathrm{O}$ "; $\mathrm{Ph}$. D. dissertation, The Pennsylvania State University. June 1959.

- 1961: The system $\mathrm{NaAlSiO}_{4}$ (nepheline) - $\mathrm{NaAlSi}_{3} \mathrm{O}_{8}$ (albite) - $\mathrm{H}_{2} \mathrm{O}$. Amer. Miner., 46, 859-884.

SENDEROV, E. E. and YUKHNEVich, G. V., 1964: On the transformation of natrolite under hydrothermal conditions. Transl. from Geokhimiya (Publ. Acad. Sci. U.S.S.R.), 1964 No. 11, 1200-1202.

Sveshizovr, V. N. and Kuznetsov, V. G., 1946: Structural relation between zeolites and natural kaolin and their transformation on heating. Izvest. Akad. Nauk, U.S.S.R., Otdel, Khim, Nauk, 1946, 25-36. Chem. Abst., 42, 6200 (1948). Swanson, H. E. and Fuyat, K., 1953: National bureau of standards. Circular 539, Vol. III.

Sørensen, H., 1962: On the occurrence of steenstrupine in the Ilímaussaq massif, Southwest Greenland. Medd. om Grønland, 167, i, p. 1-251.

Ussing, N. V., 1894: Mineralogisk-petrografiske Undersøgelser af Grønlands Nephelinsyeniter og beslægtede Bjærgarter. Medd. om Grønland, 14, p. 119. 


\section{Plate 1}

Part of Guinier-Hägg exposures of

1) Natrolite from Glen Farg.

2) Tetragonal natrolite.

Where no indices have been given on (2) the lines have been identified as lines belonging to tugtupite, $\mathrm{Na}_{8} \mathrm{Al}_{2} \mathrm{Be}_{2} \mathrm{Si}_{8} \mathrm{O}_{24}(\mathrm{Cl}, \mathrm{S})_{2}$. Unfortunately the $\mathrm{X}$-ray film of tetragonal natrolite used for the determination of the lattice constants was too thin for reproduction. 


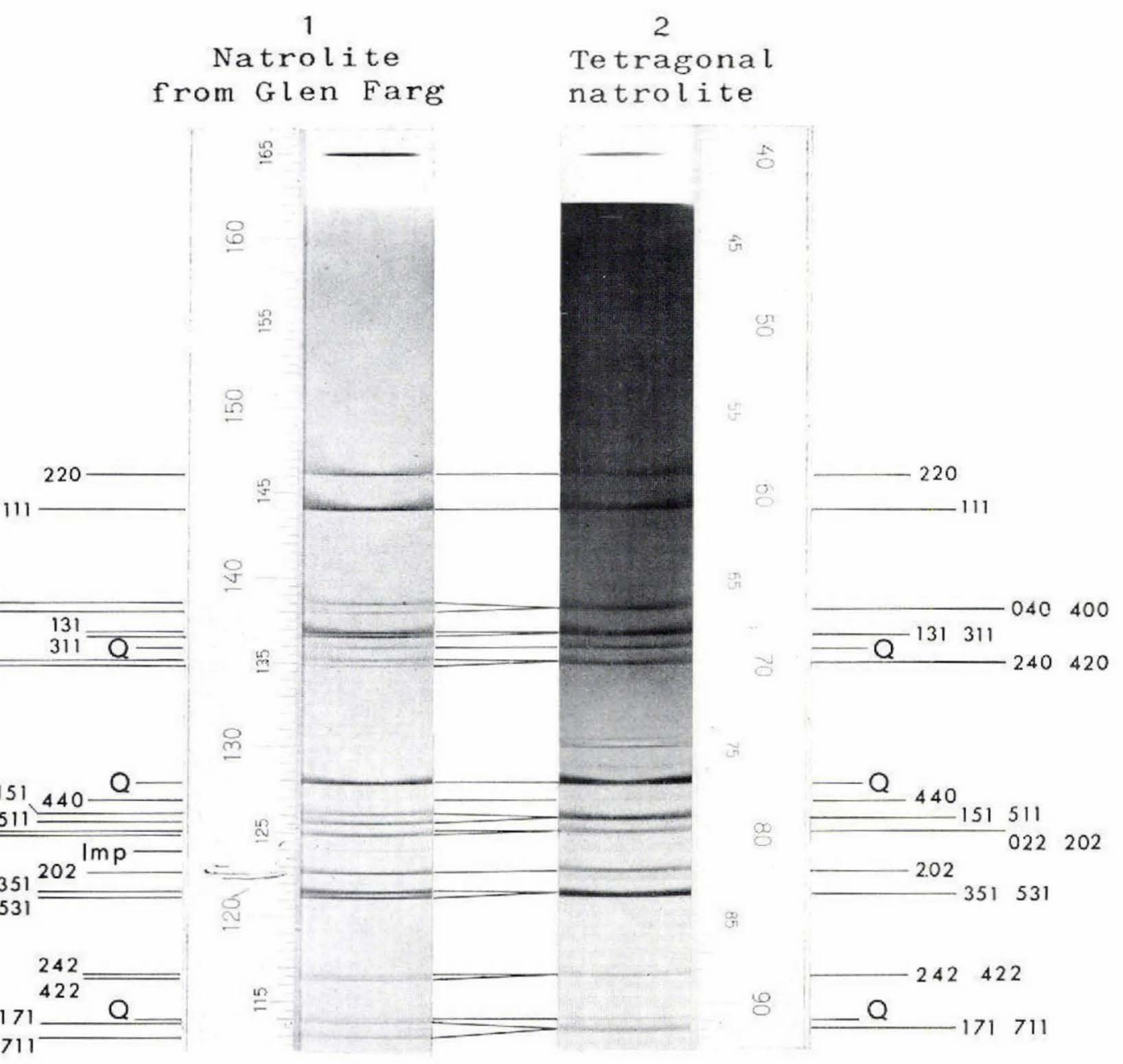

